\title{
EDITORIAL
}

\section{O MINISTERIO DA EDUCAÇÃO E CULTURA VAI AO MEIO RURAL}

O MEC institui, por portaria do Ministro, datada de 4 de janeiro, o Programa de AÇÓES SÓCIO-EDUCATIVAS E CULLTURAIS PARA O MEIO RURAL, a ter início neste ano de 1980. Nas áreas de maior necossidade, a começar pelo Nordeste, entrará em execução já, devendo estender-se a todas as outras Grandes Regiōes, a partir de 1981. Com esse programa visa - Governo contribuir para a boa estruturação das pessoas na fase de meninice e juventude e somar seus esforços a outros programas de desenvolvimento agro-pecuário. Será uma oportunidade para a educação básica, formação especial e preparação para o trabalho. Os professores - dentre as quais técnioos do ramo respectivo - e os alunos deverão fortalecer a organização social, por exemplo, a formação de cooperativas, tanto de produção como de consumo. Os empresários, fazendeiros, pecuaristas deverão ser envolvidos, não só para que tenham, amanhã, mão de obra qualificada, como para que sua contribuição valiosa seja entrasada, a fim de conseguirem melhorias na lavoura tais como assistência técnica no ramo de seu interesse.

Uma vez que as cursos de graduaçao de enfermagem já estão despertados, a exemplo do Currículo Novo da Escola Ana Neri, para a assistência à saúde dos escolares, resta à $A B E n$ traçar diretrizes sobre campus avançado para cada escola de formação de enfermeiros, técnicos e auxiliares de enfermagem ,no sentido de haver sempre, em equipes, estudantes trabalhando em comunidade, auxiliando o pessoal de saúde dos programas de cada município.

O próprio Ministério da Educação, na Portaria de 04 de janeiro, assinala que o trabalho requer o concurso de vários ministérios. Áreas da periferia das grandes metrópoles deverão ser divididas, para fins de açāo em tais nrogramas de assistência, entre as diferentes escolas de profissionais de 
saúde da Micro-região. Finalmente, nossa geração estará alcançando tempos em que diferentes conhecimentos se integram pana a ação junto ao povo. Cabe às escolas superiores de enfermagem de cada Micro-região, por ordem de antiguidade, convocarem-se e planejarem sua participação efetiva.

(HGD) 